DOI:10.2478/v10129-009-0005-7

Krzysztof Treder, Włodzimierz Przewodowski, Agnieszka Barnyk

Plant Breeding and Acclimatization Institute in Radzików, Department of Potato Protection and Seed Science in Bonin, 76-009 Bonin, Poland, tel.: (+48) 9434230 31, fax: (+48) 9434270 28,

Corresponding author: e-mail: krzysztof.treder@wp.pl

\title{
FACTORS INFLUENCING DETECTION OF POTATO LEAFROLL VIRUS AND POTATO VIRUS Y IN POTATO TUBER EXTRACTS
}

\begin{abstract}
Detection of Potato leafroll virus (PLRV) and Potato virus Y (PVY) directly in potato tubers has been influenced by several factors. The most important were: the place of tuber sampling, preincubation of tuber sap before loading into wells of microplate and duration of tubers storage after collecting from field. The concentration of both viruses was highest in the heel part of tubers, whenever tested. Preincubation of tuber sap for several hours improved true/false signal ratio for dormant tubers and enabled reliable detection of both viruses. However after natural dormancy breaking it was necessary to change Cocktail-ELISA procedure to obtain reliable results, consistent with DAS-ELISA on leaves. The sap was not preincubated but loaded into wells directly after sample collecting and immuno-enzymatic reaction was developed overnight in refrigerator.
\end{abstract}

Key words: Cocktail-ELISA, PLRV, PVY, potato seed tubers

\section{INTRODUCTION}

Potato (Solanum tuberosum) is one of the most important food crop in the world amongst wheat, rice and maize. It is a host of over 50 viruses and viroids (Brunt et al. 1996) and is propagated vegetatively, allowing viral particles to accumulate (Singh 1999). The highest economical loses are caused by Potato virus Y (PVY) and to less extent by Potato leafroll virus (PLRV). Disease control management involves in vitro propagation of healthy plants, followed by production of virus-free seed tubers, thus determination of the plant's health status is critical during this process.

The most widely utilized method for diagnosis of viral infection is the post-harvest growing-on test. This involves removing eye-plugs from the rose part of the tuber, breaking dormancy by gibberellic acid, growing them

Communicated by Edward Arseniuk 
in greenhouses during autumn/winter, visual inspection of disease symptoms followed by sampling leaves and testing by DAS-ELISA (leaf-ELISA). This method is efficient but time and cost consuming. Thus the method capable to detect viral particles directly in tuber extracts is strongly needed. Many authors tryied to use DAS-ELISA for detection of PVY and PLRV in primary and secondary infected tubers (Gugerli 1980, Gugerli and Gehringer 1980, Tamada and Harrison 1980). Application of mechanical tuber sampling device combined with chemical stimulation of dormancy breaking was reported to result in reliable detection of PVY (Gugerli 1980). This method was also suitable for PLRV detection, but chemical treatment was not necessary (Gugerli and Gehringer 1980). Contradictory to these results, Hill and Jackson (1984) reported that DAS-ELISA is not reliable for PLRV and PVY detection directly in tuber sap.

The development of nucleic acids analysis such as hybridization (Robinson and Romero 1991, Wełnicki and Żekanowski 1994, Loebenstein et al. 1997), NASBA (Leone et al. 1997, 1998), RT-PCR (Spiegel and Martin 1993, Nie and Singh 2001, Singh and Singh 1996, Singh et al. 2004) and microarrays (Boonham et al. 2003, Bystricka et al. 2005) gave possibility for direct virus detection in extracts from harvested tubers. However adaptation of molecular methods into routine tests is unpractical due to the level of labour and cost involved. Moreover it was reported that RT-PCR and Real-time PCR were less reliable for PVY detection in tuber extracts than leaf-ELISA (Fox et al. 2005). Thus there is still demand for sensitive, efficient and cheap methods for virus detection.

The Cocktail-ELISA, in which sample and conjugate are incubated simultaneously in the wells of the microplate was reported to be more sensitive than DAS-ELISA (Flegg and Clark 1977, van den Heuvel and Peters 1989). After optimization of the procedure we have successfully applied Cocktail-ELISA for PLRV detection in tuber extracts (Treder and Lewosz 2000). This paper presents preliminary results of optimization of the test for simultaneous detection of PLRV and PVY in tuber extracts.

\section{MATERIALS AND METHODS}

\section{Reagents}

The following reagents were obtained from Sigma-Aldrich: di-thiotreitol, polyvinyl pirolydone K-20 (PVP) and Tween 20. ELISA microplates were obtained from Nunc (Biokom, Poland). ELISA kit for PLRV and PVY detection were prepared by authors. The remaining reagents were purchased in POCH Gliwice, Poland. 


\section{Potato tubers}

Potato tubers were kept in the dark at about $10^{\circ} \mathrm{C}$. Tubers with secondary infection and comparable virus-free tubers were from plants grown at the Department of Seed Science and Potato Protection in Bonin of Plant Breeding and Acclimatization Institute in Radzików. Secondary infected tubers were choosen as a model for investigation because of lower concentration of PLRV in heel tissue of the tuber than in relevant part of primary infected tubers (Tamada and Harrison 1980).

\section{Tuber extracts}

Heel and rose ends of ten virus-free or virus-infected tubers were grated and the pulp was pressed by muslin. Obtained sap was diluted directly in sample buffer $(0.02 \mathrm{M}$ sodium phosphate $\mathrm{pH} 7.4,0.15 \mathrm{M}$ sodium chloride, $2 \%$ PVP, $0.05 \%$ Tween 20 and $0.005 \%$ di-thiotreitol). The samples were tested simultaneously by DAS-ELISA and Cocktail-ELISA for comparative purposes.

\section{DAS-ELISA}

The procedure of Clark and Adams (1977) was used for DAS-ELISA. Wells of microplates were sensitized by adding $250 \mathrm{ml}$ of $1 \mathrm{mg} / \mathrm{ml} \gamma$-globulin in coating buffer $(0,05 \mathrm{M}$ sodium carbonate, $\mathrm{pH} 9.6)$. After a 3-hr incubation at $37^{\circ} \mathrm{C}$, wells were vigorously rinsed with wash buffer $(0.02 \mathrm{M}$ sodium phosphate $\mathrm{pH}$ 7.4, $0.05 \%$ Tween $20, \mathrm{pH}$ 7.6) and filled with tuber extracts diluted in sample buffer $\left(200 \mathrm{ml}\right.$ per well). The samples were incubated overnight at $4^{\circ} \mathrm{C}$. The wells were then flushed with wash buffer, filled with alkaline phosphatase conjugated ă-globulins diluted 1000 -fold in the conjugate buffer $(0.02 \mathrm{M}$ sodium phosphate, $\mathrm{pH} 7.4,0.15 \mathrm{M}$ sodium chloride, $2 \% \mathrm{PVP}, 0,05 \%$ Tween 20 and $1 \%$ gelatin) and incubated for $3-\mathrm{hr}$ at $37^{\circ} \mathrm{C}$. The microplates were then washed and $200 \mathrm{ml}$ of substrate $(0.1 \% \mathrm{p}$-nitrophenyl phosphate disodium salt (p-NPP) in 1 $\mathrm{M}$ diethanolamine, $\mathrm{pH}$ 9.8), was added to each well. Microplates were incubated in darkness at room temperature for $4 \mathrm{hrs}$ and absorbance (A405) was measured at $405 \mathrm{~nm}$ on the Dynatech MR5000 colorimeter.

\section{Cocktail-ELISA}

Everything remained the same as in DAS-ELISA except the sample extracts and conjugate were added together ( $200 \mathrm{ml}$ total volume) and incubated overnight at $4^{\circ} \mathrm{C}$.

Threshold: samples were termed positive when the mean absorbance reading (from four replicates) exceeded two times the average of the sap samples from virus-free tubers prepared in the same conditions.

\section{Post-harvest testing of tubers by Cocktail-ELISA}

Forty five tubers of potato cultivars Van Gogh and Ina were tested by Cocktail-ELISA one month (Table 3) and four months (Table 4) after har- 
vesting. The tubers were secondary infected by PVY (Van Gogh) and PLRV (Ina). To simplify sample collection procedure and adjust it for routine diagnostic samples were taken by slicing heel or rose part of tuber and squeezing out the sap on the roller press. Two drops of sap from one slice were collected into tube containing $450 \mu \mathrm{L}$ of sample buffer. Tuber extracts were transferred into microplate wells $(100 \mu \mathrm{l})$ directly or after pre-incubation in room temperature for $3 \mathrm{~h}$ or $24 \mathrm{~h}$, followed by addition of $100 \mu \mathrm{l}$ of conjugate (1/1000 in dilution buffer) into wells. Next microplates were incubated for $24 \mathrm{~h}$ in $4^{\circ} \mathrm{C}$. Freshly prepared substrate $(0.1 \% \mathrm{p}$-nitrophenyl phosphate in $1 \mathrm{M}$ diethanolamine buffer ( $\mathrm{pH}$ 9.6) was added, followed by incubation in the dark for $1-6 \mathrm{hrs}$ at room temperature or for $24 \mathrm{hrs}$ at $4^{\circ} \mathrm{C}$ prior reading A405.

\section{Post-harvest growing-on test (leaf ELISA)}

Eye-plugs from the rose end of tubers tested by Cocktail-ELISA were removed, followed by breaking the dormancy by gibberellic before planting it in the glasshouse.

Plantlets were tested by DAS-ELISA (leaf-ELISA) 2 months later for virus infection. Modified procedure of Clark and Adams (1977) was used for leaf ELISA. Microplates were coated by shaking for $1 \mathrm{~h}$ in room temperature with $100 \mu \mathrm{L}$ of ă-globulins $(1 \mu \mathrm{g} / \mathrm{ml}$ in coating buffer). Plates were rinsed 4 times with wash buffer. Tissue extracts were obtained on roller press by collecting one drop into tubes filled with $475 \mu \mathrm{L}$ of sample buffer (without di-thiotreitol). Wells of microplates were filled with $100 \mu 1$ of diluted extracts and shaken for $1 \mathrm{hr}$ at room temperature and washed. This is followed by adding $100 \mu \mathrm{L}$ of conjugate and shaken for $2 \mathrm{hrs}$ at room temperature. Freshly prepared substrate (p-NPP) was added. Plates were incubated in the dark for $4 \mathrm{hrs}$ at room temperature. A405 readings were recorded several times during this period at $405 \mathrm{~nm}$ on Dynatech MR5000 colorimeter.

\section{RESULTS}

\section{Comparison of DAS-ELISA with cocktail-ELISA for detection of PLRV and PVY in dilution of tuber sup}

Cocktail-ELISA was compared to DAS-ELISA in sensitivity using PLRV and PVY-infected potato tubers (cultivars Sokół for PVY and Osa for PLRV). Virus-free tubers were used as negative control. Absorbance obtained after $2 \mathrm{hrs}$ of signal development was shown to be optimal (Table 1 and 2).

All dilutions of extract prepared from PLRV-infected tubers had higher absorbance values in the Cocktail-ELISA than in DAS-ELISA, while most dilutions had A405 readings three to four times higher in Cocktail-ELISA. 
Dilutions of control extract, prepared from virus-free tuber gave significantly lower A405 values than virus-containing samples. The level of background reaction for five and ten fold diluted control extract was similar in DAS- and Cocktail-ELISA. However, background tended to increase slightly with increase of virus dilution in Cocktail-ELISA. Finally Cocktail-ELISA allowed detection of PLRV in all tested dilutions whereas in DAS-ELISA, detection was limited to extracts diluted fivefold (Table 1).

Comparison of DAS-ELISA and Cocktail-ELISA sensitivity of PLRV

Table 1 detection in serial tuber extract dilutions

\begin{tabular}{ccccccccccccc}
\hline \multicolumn{1}{c}{ DAS-ELISA } & \multicolumn{7}{c}{ Cocktail-ELISA } \\
\hline $\begin{array}{c}\text { Dilu- } \\
\text { tions }\end{array}$ & PLRV & SD & Control & SD & Threshold $\begin{array}{c}\text { Dilu- } \\
\text { tions }\end{array}$ & PLRV & SD & Control & SD & Threshold \\
\hline 5 & 0.991 & 0.046 & 0.244 & 0.055 & 0.488 & 5 & 1.741 & 0.248 & 0.284 & 0.064 & 0.568 \\
10 & 0.515 & 0.080 & 0.255 & 0.048 & 0.510 & 10 & 1.735 & 0.109 & 0.233 & 0.083 & 0.466 \\
15 & 0.452 & 0.063 & 0.250 & 0.050 & 0.500 & 15 & 1.688 & 0.044 & 0.221 & 0.024 & 0.442 \\
20 & 0.400 & 0.015 & 0.236 & 0.047 & 0.472 & 20 & 1.255 & 0.054 & 0.194 & 0.014 & 0.388 \\
\hline
\end{tabular}

PLRV - extract from PLRV-infected tubers. Control - extract from healthy tubers. SD - value of standard deviation. Threshold - value above which samples were considered "infected" (double value of controls averages).

Comparison of PVY detectability by DAS- and Cocktail-ELISA in serial tuber extract dilutions

\begin{tabular}{rrrrrrrrrrrrr}
\hline \multicolumn{1}{c}{ DAS-ELISA } \\
\hline $\begin{array}{c}\text { Dilu- } \\
\text { tions }\end{array}$ & PVY & SD & Control & SD & Threshold & $\begin{array}{c}\text { Dilu- } \\
\text { tions }\end{array}$ & PVY & SD & Control & SD & Threshold \\
\hline 5 & 1.699 & 0.044 & 1.382 & 0.198 & 2.764 & 5 & 1.671 & 0.045 & 0.460 & 0.050 & 0.921 \\
10 & 1.645 & 0.098 & 1.356 & 0.173 & 2.712 & 10 & 1.915 & 0.018 & 0.538 & 0.042 & 1.076 \\
25 & 0.755 & 0.058 & 0.922 & 0.142 & 1.844 & 25 & 1.413 & 0.052 & 0.496 & 0.045 & 0.992 \\
50 & 0.617 & 0.072 & 0.665 & 0.167 & 1.330 & 50 & 0.673 & 0.031 & 0.284 & 0.009 & 0.568 \\
100 & 0.456 & 0.027 & 0.538 & 0.103 & 1.076 & 100 & 0.375 & 0.048 & 0.225 & 0.019 & 0.450 \\
\hline
\end{tabular}

PVY - extract from PVY-infected tubers. Control - extract from healthy tubers. $(+/-)$ - value of standard deviation. Threshold - value above which samples were considered "infected" (double value of controls averages).

For PVY-infected tubers, the differences in A405 readings between Cocktail- and DAS-ELISA were considerably lower than for PLRV and has been observed only for ten - twenty five fold diluted extracts while for all other dilutions the values were similar for both ELISA variants (Table 2). However in DAS-ELISA the A405 readings were unacceptably high for all dilutions prepared from control extract and for twenty five and fifty fold dilutions values were higher than obtained for correspondingly diluted extract prepared from PVY-infected tubers. Conversely, for the 
Cocktail-ELISA method, the background values were significantly lower in most extract dilutions, resulting in the threshold values three to four fold lower than in DAS-ELISA. Diluting virus-containing extract resulted in background reduction what strongly influenced threshold of DAS-ELISA and to lower extent - of Cocktail-ELISA.

Finally, it was shown that PVY binding was inhibited by more concentrated tuber extract in Cocktail-ELISA (Table 2, fivefold diluted extract) but had no or little influence for PLRV (Table 1). In more diluted samples inhibitory activity of sap was not observed.

\section{Post-harvest virus testing by Cocktail-ELISA}

For field experiment two cultivars were chosen: PVY-infected Van Gogh and PLRV-infected Ina. Forty five tubers of each cultivar were tested by Cocktail-ELISA one month (Table 3) and four months (Table 4) post-harvesting.

Table 3

Detection of PLRV and PVY by Cocktail-ELISA in dormant tubers

\begin{tabular}{|c|c|c|c|c|}
\hline Pre-incubation & Virus & Sampling area & Threshold & Infected (\%) \\
\hline \multirow{4}{*}{ None } & \multirow{2}{*}{ PLRV } & Rose & 0.544 & 0.0 \\
\hline & & Heel & 0.544 & 0.0 \\
\hline & \multirow{2}{*}{ PVY } & Rose & 0.362 & 17.8 \\
\hline & & Heel & 0.362 & 49.9 \\
\hline \multirow{2}{*}{$24 \mathrm{~h}$} & \multirow{2}{*}{ PLRV } & Rose & 0.340 & 26.7 \\
\hline & & Heel & 0.340 & 84.4 \\
\hline \multirow{2}{*}{$3 \mathrm{~h}$} & PLRV & Heel & 0.090 & 93.0 \\
\hline & PVY & Heel & 0.102 & 100.0 \\
\hline \multirow{2}{*}{ Leaf-ELISA } & PLRV & Leaf & 0.030 & 93.0 \\
\hline & PVY & Leaf & 0.040 & 100.0 \\
\hline
\end{tabular}

Pre-incubation - duration of tuber extract incubation before pipetting into microplate wells. Sampling area - tuber area where tissue samples were cut from. Infected - plants for which the average absorbance values exceeded two times the average of A 405 of the samples from virus-free tubers

Eye-plugs were removed from all tested tubers and growing-on test was performed as a reference (rows entitled "leaf-ELISA" in table 3 and 4). The heel end of the tuber was found to be optimal location for sampling. However, tubers stored four months started to sprout and difference of virus concentration in heel and rose ends tissues was lower than for tubers tested one month after harvest.

Results shown in table 3 revealed that in extracts from tubers tested one month after harvest background was lowered approximately six times for PLRV and three times for PVY by pre-incubation in room temperature. Af- 
ter this treatment, PVY was detected in all tested tubers and PLRV in 98\% of tubers, what corresponds well to results obtained by reference leaf-ELISA.

Table 4

Detection of PLRV and PVY by Cocktail-ELISA in tubers after natural dormancy breaking

\begin{tabular}{|c|c|c|c|}
\hline Pre - incubation & Virus & Sampling area & Infected $(\%)$ \\
\hline \multirow{4}{*}{$3 \mathrm{~h}$} & \multirow{2}{*}{ PLRV } & Rose & 93.0 \\
\hline & & Heel & 93.0 \\
\hline & \multirow{2}{*}{ PVY } & Rose & 35.6 \\
\hline & & Heel & 46.7 \\
\hline \multirow{4}{*}{ None } & \multirow{2}{*}{ PLRV } & Rose & 76.7 \\
\hline & & Heel & 88.4 \\
\hline & \multirow{2}{*}{ PVY } & Rose & 44.4 \\
\hline & & Heel & 55.5 \\
\hline \multirow{4}{*}{$\begin{array}{l}\text { None, overnight signal } \\
\text { development }\end{array}$} & \multirow{2}{*}{ PLRV } & Rose & 93.0 \\
\hline & & Heel & 93.0 \\
\hline & \multirow{2}{*}{ PVY } & Rose & 98.0 \\
\hline & & Heel & 100.0 \\
\hline \multirow{2}{*}{ Leaf-ELISA } & PLRV & Leaf & 93.0 \\
\hline & PVY & Leaf & 100.0 \\
\hline
\end{tabular}

Pre-incubation - duration of tuber extract incubation before pipetting into microplate wells. Sampling area - tuber area where tissue samples were cut from. Infected - plants for which the average absorbance values exceeded two times the average of A405 of the samples from virus-free tubers

However after four months storage, pre-incubation was beneficial for PLRV but not for PVY (Table 4). For PVY, results consistent with leaf-ELISA were obtained by testing extracts without pre-incubation and by developing enzyme activity overnight in $4^{\circ} \mathrm{C}$ degree. This also resulted in higher A405 readings for PLRV-infected tubers. Absorbance values obtained for tubers stored one month were higher than for tubers tested four months post-harvesting. Thus longer storage lowered test sensitivity. Nonetheless, detectability was the same as for reference leaf-ELISA.

\section{DISCUSSION}

In this study we compared the efficacy of Cocktail-ELISA with DAS-ELISA for detection of PLRV and PVY in potato tuber extracts. In summary, we have shown that Cocktail-ELISA was more sensitive than DAS-ELISA allowing detection of both PVY and PLRV in all tested dilutions of virus-containing extracts (Tables 1 and 2). This effect was also ob- 
served for detection of PLRV in potato leaves (van den Heuvel and Peters 1989), and for ACLSV in various apple cultivars (Flegg and Clark 1979). The background was higher than in DAS-ELISA but differences were insignificant. Van den Heuvel and Peters (1989) proposed that improvement in antigen detection caused by Cocktail-ELISA could be a result of immobilization of a larger antigen-conjugate complexes to PLRV antigen, binding of more conjugate molecules to viral antigen or decreased leakage of antigen-antibody complexes from solid phase due to omission of one washing step. All above explanation fit well for improvement of PLRV detection in tuber sap because our results are similar to these described for PLRV detection in leaves (van den Heuvel and Peters 1989). However results obtained for PVY can not be explained this way. Even though there also absorbance values were higher for most dilutions prepared from PVY containing extracts, difference was not as strong as for PLRV. Moreover there was no difference for fifty times diluted extract. Furthermore for all tested dilutions the background values were two-three times lower in Cocktail-ELISA. Thus it seems that this high background reduction is responsible for improved detection of PVY. In view of results obtained in our work it seems that application of Cocktail-ELISA improves each virus detection but the way in which this improvement is achieved depends on virus properties.

The results of our investigation showed that reliable detection of PLRV and PVY has been influenced by such parameters as: place of tissue sampling, period of extracts pre-incubation and period of tuber storage before cocktail-ELISA. The heel area of the tuber was optimal place of sampling for both viruses. However during several months lasting storage, difference in concentrations of viral particles between heel and rose end has decreased, probably because of virus movement into eyes after dormancy breaking. According to Gugerli and Gehringer (1980) in sprouted tubers PVY was more concentrated at the rose end. We have found the largest concentration of PVY in the heel end of dormant tubers (one month after harvesting from the field) as well as after physiological dormancy breaking (four months after harvest). This difference in results could be explained by accelerated accumulation of PVY in the rose end after rindite-treatment used by Gugerli and Gehringer (1980). PLRV has occurred in higher concentration at the heel end regardless of tubers age. This result is consistent with literature data (Gugerli 1980, Gugerli and Gehringer 1980, Tamada and Harrison 1980). Possible explanation of the large concentration of both viruses in heel end tissue is that much of viral particles have been transported to the tuber via stolon from others parts of the plant (Tamada and Harrison 1980).

Tamada and Harrison (1980) observed that background reduction could be obtained by pre-incubating the extracts at room temperature. Thus we tested this factor and our result shows that pre-incubation of extracts in room temperature before Cocktail-ELISA, is essential for both viruses 
when tubers are tested one month after harvesting. The non-specific reactions of extracts of virus-free tubers were very high if Cocktail-ELISA was performed directly after sampling and this background was significantly minimized by pre-incubating extracts for $3 \mathrm{~h}$ at room temperature. This is consistent with observation of Tamada and Harrison (1980). Due to this treatment we have obtained for both viruses the same results as by reference leaf-ELISA. This was beneficial for PLRV also when tubers have been tested four months after harvesting. However after storage, pre-incubation of extracts from tuber infected by PVY lowered detectability of this virus in spite of minimizing non-specific reactions. In this cause we have obtained result consistent with leaf-ELISA by pouring fresh extracts into microplate wells and incubating microplate with p-nitrophenyl phosphate overnight in $4^{\circ} \mathrm{C}$. Similarly, after this procedure, mean absorbance values for PLRV were also higher than after pre-incubation despite of increased non-specific reactions level. It is possible that in extracts from sprouted tubers reactions deleterious for viral particles occurs, probably proteolytic in nature. In the same conditions of cocktail-ELISA procedure we have observed higher absorbance values one month than four months after harvesting. This difference could be explained similarly by increased proteolytic activity in extracts from sprouted tubers. However experimental work is necessary to prove or reject this presumption.

Our results show that detection of viruses directly in extracts from tubers is possible, regardless of longitude of tuber storage. Careful selection of the procedure of cocktail-ELISA eliminates the reasons for which ELISA is not reliable in estimation of tuber infection. However work on method optimization, adaptation for other viruses (PVA, X, M, S) and estimation of its reliability and usefulness in routine tests, is necessary. Our results (Treder and Lewosz 2000) have shown that amplification of the alkaline phosphatase reaction by enzymatic system (diaphorase and alcohol dehydrogenaze) improves cocktail-ELISA sensitivity forty times. Thus additional work is necessary for developing optimized test for sensitive tuber indexation.

\section{ACKNOWLEDGMENTS}

The author wish to thank dr Aurelie Rakotontafara, MSc Betty Chung and dr Andrew Firth for discussions and the critical reading of the manuscript. This study was financially supported by Polish Ministry of Agriculture (grant 4-3-00-7-03).

\section{REFERENCES}

Boonham, N., Walsh, K., Smith, P., Madagan, K., Graham, I., Barker, I. (2003). Detection of potato viruses using microarray technology: towards a generic method for plant viral disease diagnosis. generic method for plant viral disease diagnosis. J. Virol. Methods 108, 181-187. 
Brunt, A.A., Crabtree, K., Dallwitz, M.J., Gibbs, A.J., Watson, L. and Zurcher, E.J. (eds.) (1996). Plant Viruses Online: Descriptions and Lists from the VIDE Database. Version: 20th August 1996. URL http://biology.anu.edu.au/Groups/MES/vide/

Bystricka, D., Lenz, O., Mraz, I., Piherova, L., Kmoch, S., Sip, M. (2001). Oligonucleotide-based microarray: a new improvement in microarray detection of plant viruses. J. Virol. Methods. 128, 176-82.

Clark, M.F., Adams, A.N. (1977). Characteristics of the microplate method enzyme-linked immunosorbent assay for detection of plant viruses. J. Gen. Virol. 34, 475-483.

Flegg, C. L., Clark, M. F. (1979). The detection of apple chlorotic leafspot virus by a modified procedure of enzyme-linked immunosorbent assay (ELISA). Ann. Appl. Biol. 91, 61-65.

Fox, A., Evans, F., Browning, I. (2005). Direct tuber testing for Potato Y potyvirus by real-time RT-PCR and ELISA: reliable options for post-harvest testing? EPPO Bulletin 35, 93-97.

Gugerli, P. (1979). Potato virus A and Potato leafroll virus: purification, antiserum production and serological detection in potato and test plants by enzyme-linked immunosorbent assay (ELISA). Phytopathol. Z. 96, 97-107.

Gugerli, P. (1980). Potato leafroll virus concentration in vascular region of potato tubers examined by enzyme-linked immunosorbent assay (ELISA). Potato Res. 23, 137-141.

Gugerli, P., Gehringer, W. (1980). Enzyme-linked immunosorbent assay (ELISA) for the detection of Potato leafroll virus and Potato virus $Y$ in potato tubers after artificial break of dormancy. Potato Res. 23,353-359.

Heuvel van den, J.F.J.M., Peters, D. (1989). Improved detection of Potato leafroll virus in plant material and in aphids. Phytopathology 79, 963-967.

Hill, S. A., Jackson, E. A. (1984). An investigation of the reliability of ELISA as a practical test for detecting Potato leafroll virus and Potato virus $Y$ in tubers. Plant Pathology 33, 21-26.

Leone, G., van Schijndel, H.B., van Gemen, B., Kramer, F.R., Schoen, C.D. (1998). Molecular beacon probes combined with amplification by NASBA enable homogeneous, real-time detection of RNA. Nucleic Acids Res. 26, 2150-2155.

Leone, G., van Schijndel, H.B., van Gemen, B., Schoen, C.D. (1997). Direct detection of Potato leafroll virus in potato tubers by immunocapture and the isothermal nuclec acid amplification method NASBA. J. Virol. Methods 66, 19-27.

Loebenstein, G., Akad, F., Filatov, V., Sadvakasova, G., Manadilova, A., Bakelman, H., Teverovsky, E., Lachmann O., David, A. (1997). Improved detection of potato leafroll luteovirus in leaves and tubers with a digoxigenin-labeled cRNA probe. Plant Disease 81, 489- 491.

Nie, X., Singh, R.P. (2001). A novel usage of random primers for multiplex RT-PCR detection of virus and viroid in aphids, leaves, and tubers. J. Virol. Methods 91, 37-49.

Robinson, D. J., Romero, J. (1991). Sensitivity and specificity of nucleic acid probes for potato leafroll luteovirus detection. J. Virol. Methods 34, 209-219.

Singh, M., Singh, R. (1996). Factors affecting detection of PVY in dormant tubers by reverse transcription polymerase chain reaction and nucleic acid spot hybridization. J. Virol. Methods 60, 47-57.

Singh, R.P. (1999). Development of the molecular methods for potato virus and viroid detection and prevention. Genome 42, 592-604

Singh, R.P., Dilworth, A.D., Singh, M., McLaren, D.L. (2004). Evaluation of a simple membrane-based nucleic acid preparation protocol for RT-PCR detection of potato viruses from aphid and plant tissues. J. Virol. Methods 121, 163-170.

Spiegel, S., Martin, R.R. (1993). Improved detection of Potato leafroll virus in dormant potato tubers and microtubers by the polymerase chain reaction and ELISA. Ann. Appl. Biol. 122, 493-500.

Takanami, Y., Kubo, S. (1979). Enzyme assisted purification of two phloem-limited plant viruses: tobacco necrotic dwarf and potato leafroll. J. Gen. Virol. 44,153-159.

Tamada, T., Harrison, B.D. (1980). Factors affecting the detection of Potato leafroll virus in potato foliage by enzyme-linked immunosorbent assay. Ann. Appl. Biol. 95, 209-219.

Treder, K. (2000). Czułe metody wykrywania wirusa liściozwoju ziemniaka. In: Metody stosowane do identyfikacji odmian i wykrywania niektórych patogenów ziemniaka. Instrukcje, IHAR Oddz. Bonin, pp. 3-13.

Treder, K., Lewosz, J. (2000). Zastosowanie metod molekularnych do wykrywania wirusa liściozwoju ziemniaka (PLRV). Postępy w Ochronie Roślin 40, 177-187.

Wełnicki, M., Żekanowski, C. (1994). Digoxigenin-labelled molecular probe for the simultaneous detection of three potato pathogens: potato spindle tuber viroid (PSTVD), Potato virus Y (PVY), and Potato leafroll virus (PLRV). Acta Biochim. Polon. 41, 473-475. 